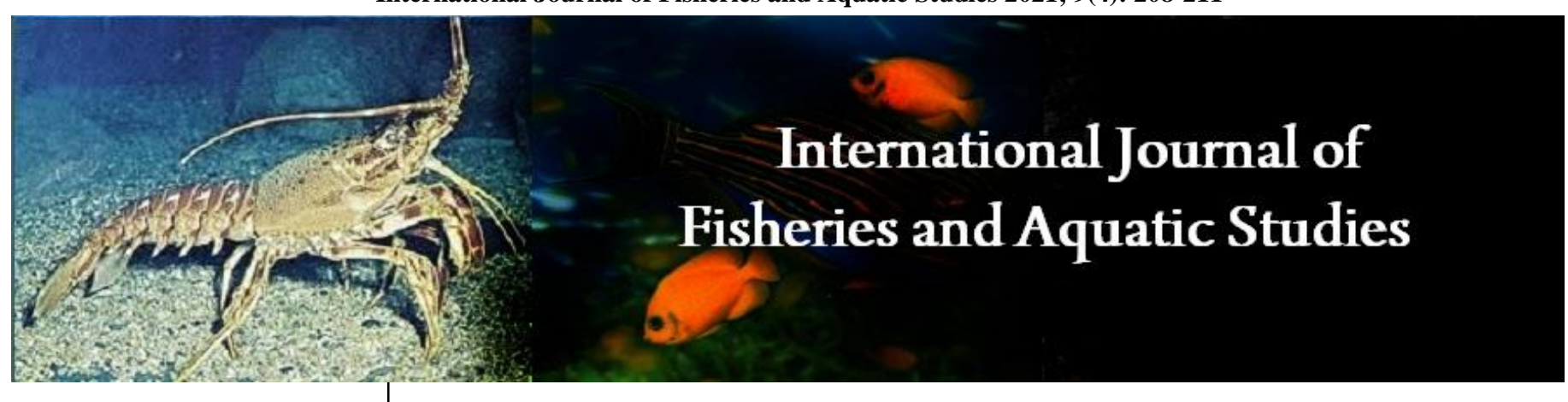

E-ISSN: 2347-5129

P-ISSN: 2394-0506

(ICV-Poland) Impact Value: 5.62

(GIF) Impact Factor: 0.549

IJFAS 2021; 9(4): 208-211

(C) 2021 IJFAS

www.fisheriesjournal.com

Received: 04-05-2021

Accepted: 06-06-2021

Renu Chaudhari

Pest and Parasite Research

Laboratory, Department of

Zoology, Bareilly College,

Bareilly, Uttar Pradesh, India

Kamal Kumar Saxena

Pest and Parasite Research

Laboratory, Department of

Zoology, Bareilly College,

Bareilly, Uttar Pradesh, India
Corresponding Author:

Renu Chaudhari

Pest and Parasite Research

Laboratory, Department of

Zoology, Bareilly College,

Bareilly, Uttar Pradesh, India

\section{Study of changes in the behaviour of Channa punctatus exposed to carbamate pesticide carbaryl}

\author{
Renu Chaudhari and Kamal Kumar Saxena
}

DOI: https://doi.org/10.22271/fish.2021.v9.i4c.2534

\begin{abstract}
Present work was undertaken to study the behavioural alterations and morphological deformities in the freshwater fish Channa punctatus developed due to exposure to different sublethal concentrations of carbamate pesticide carbaryl. Channa punctatus were exposed to concentrations ranging between $0.1 \mathrm{ppm}$ to $1.31 \mathrm{ppm}$ in in vitro conditions in the laboratory. $100 \%$ mortality was observed due to exposure to 1.17 ppm or more concentrations of carbaryl. Below this concentration fish remained alive but several morphological and behavioral changes were observed. It shows that the change in the aquatic environment causes altered behavioural responses in the animals living in it. Channa punctatus in this toxic medium exhibited erratic movements, hyperactivity, restlessness, and loss of buoyancy and they started swimming at the surface of water. The response of the fish towards toxicity was dependent on concentration of carbaryl and length of exposure. The changes in behavioural parameters were both time and dose dependent.
\end{abstract}

Keywords: Channa punctatus, carbamate, carbaryl, sublethal and behavioural response

\section{Introduction}

Fish has great importance as a secondary consumer in the food chain; this significance is magnified as it forms a major food product for higher trophic levels. Rapid industrialization in India has resulted in the substantial increase in the liquid waste which is directly discharged in open land or into nearby natural water causing several environmental problems such as surface water logging, groundwater contamination and increasing the salinity of good quality land due to presence of high-quality salts (Ramona et al., 2001) ${ }^{[16]}$. Discharge of effluents into freshwater system deplete the dissolved oxygen content and, by interfering with respiratory metabolism cause heavy mortality (Quasim and Siddique, 1960; David and Ray, 1966; Venkataraman, 1966; Hingoroni et al. 1979) ${ }^{[15,4,20,7]}$. Pollution of aquatic environment by domestic and untreated or partially treated industrial effluents greatly contributes to massive killing of fish and other important aquatic animals (Kumari and Ram Kumari, 1997; Saxena and Seth, 2002) ${ }^{[11,19]}$. Due to high chemical diversity of organic pollutants in pulp and paper mill effluent, a high variety of toxic effects on aquatic communities in recipient water have been observed (Kim Oanha, 1996 and Yen et al., 1996) ${ }^{[10,21]}$.

Pesticide is any substance or mixture of substances intended for preventing destroying, repelling, or mitigating any pest. Their application is in most effective and accepted means for protection of plants from pests and has contributed significantly to enhance agricultural productivity and crop yield. Although there are benefits to the use of pesticides, there are also drawbacks such as pollution and toxicity to non-target animals. In an ideal situation, a pesticide should affect exactly on the target and get degraded completely into harmless compounds. This, however, seldom occurs and only a small fraction of the pesticide hits the target pests while the remaining drifts into the environment (Draper and Street, 1981; Huff and Batsell, 1977; Metcalfe, 1995; Rishi and Grewal, 1995 and Ecobichon, 1998) [5, 8, 13, 17, 6]. Among all types of pollution, aquatic pollution is of greater concern because every kind of life depends on water.

Many pesticides used in agricultural sector, get washed into the water bodies thus affecting the quality of water and causes several structural and functional changes in the biota. The aquatic habitat and its water quality are the main factor that affecting fish survival and production. 
Direct or indirect exposure of fish to pesticides and their consequent toxicity are of great importance because contaminated fishes have adverse effects on the health of human beings.

The present study was undertaken to evaluate the aquatic toxicity of carbaryl with special emphasis on behaviour of freshwater fish Channa punctatus.

\section{Material and Method}

In the present study specimens of freshwater fish Channa punctatus (Bloch; Family: Channidae and Order: Channiformes) were collected from local water bodies. The fishes were acclimatized for one week under laboratory conditions. During the period of acclimatization, the fishes were fed, after every 24 hours. Acclimatized healthy fishes showing normal activities were selected for chronic toxicity tests. After acclimation, the fishes were divided into experimental and control groups. The experimental groups of fishes were exposed to sub lethal concentration of carbaryl for a period of $144 \mathrm{hrs}$. A group of ten healthy fishes of average weight (4 to $4.5 \mathrm{gm}$ ) and of average length $(6.8$ to $8.5 \mathrm{~cm})$ were selected for the present study. After exposing the test fish to sub lethal concentrations of carbaryl, the survival and behaviour of test fish was studied for 30 days.

\section{Results}

\section{A. Effect of carbaryl on mortality in Channa punctatus}

Carbaryl, at the concentration of more than $1.11 \mathrm{ppm}$ showed $100 \%$ mortality in Channa punctatus with in few days of exposure. The concentrations between $0.5 \mathrm{ppm}$ and $0.1 \mathrm{ppm}$ caused lethality and the fish died within 30 days exposure period (Table 1 and 2). The percentage of mortality depended upon the concentration of carbaryl. The concentrations of
$0.1 \mathrm{ppm}, 0.5 \mathrm{ppm}$ and $1.0 \mathrm{ppm}$ were sublethal for Channa punctatus for the exposure period of 30 days. Mortality of 1 or 2 fishes of exposed group was recorded in first few days of exposure period and after that the remaining fishes adapted themselves and survived for the remaining period.

\section{B. Effect of carbaryl on the behaviour and structure of Channa punctatus}

During exposure to different sublethal concentrations of carbaryl, altered behavioural and structural changes such as restlessness, hyperactivity, erratic swimming, frequent surfacing, discoloration of skin, loss of balance etc. were seen in Channa punctatus.

At the beginning of the exposure period, fishes stopped swimming to give response to sudden changes in the environment. After some time, they started swimming faster than their normal speed to avoid toxicity caused by carbaryl in water.

Fishes also started gulping air by frequent surfacing to cope up with the deficiency of oxygen. They stretched their body out of the water and tried to jump out of the aquarium. The skin showed decrease in pigmentation with increase in exposure period. At higher sublethal concentrations of carbaryl the fish became lethargic and showed abrupt and erratic swimming with loss of balance.

When the fishes were transferred to the aquaria containing this compound, they became restless, showed hyperactivity and erratic swimming. At the beginning they stopped swimming and accumulated at the bottom but after some time they started swimming faster to their normal speed. They started frequent surfacing to get more and more oxygen. After some time, they started to lose their balance.

Table 1: Summary of toxicity experiments on Channa punctatus exposed to different concentrations of carbaryl.

\begin{tabular}{|c|c|c|c|c|c|c|c|c|}
\hline \multirow{2}{*}{$\begin{array}{l}\text { No. of test } \\
\text { fishes }\end{array}$} & \multirow{2}{*}{$\begin{array}{l}\text { Conc } \\
\text { in ppm }\end{array}$} & \multicolumn{7}{|c|}{ Exposure period in days } \\
\hline & & 1 & 5 & 10 & 15 & 20 & 25 & 30 \\
\hline 5 & 1.31 & $\begin{array}{c}\text { All died in } \\
18 \mathrm{hrs} \text {. }\end{array}$ & - & - & - & - & - & - \\
\hline 5 & 1.25 & $\begin{array}{l}\text { All died in } \\
23 \mathrm{hrs} \text {. }\end{array}$ & - & - & - & - & - & - \\
\hline 5 & 1.22 & $\begin{array}{l}3 \text { died } / \\
2 \text { alive } \\
\end{array}$ & $\begin{array}{l}4 \text { died / } \\
1 \text { alive }\end{array}$ & All died & - & - & - & - \\
\hline 5 & 1.17 & $\begin{array}{l}4 \text { died / } \\
1 \text { alive }\end{array}$ & $\begin{array}{l}3 \text { died / } \\
2 \text { alive }\end{array}$ & All died & All died & - & - & - \\
\hline 5 & 1.15 & All alive & All alive & All alive & All alive & $\begin{array}{l}1 \mathrm{died} / \\
4 \text { alive }\end{array}$ & $\begin{array}{l}2 \text { died/ } \\
3 \text { alive }\end{array}$ & $\begin{array}{l}3 \text { died/ } \\
2 \text { alive }\end{array}$ \\
\hline 5 & 1.11 & All alive & All alive & All alive & All alive & All alive & $\begin{array}{l}1 \text { died/ } \\
\text { 4alive }\end{array}$ & 3 alive \\
\hline 5 & 1.00 & All alive & All alive & All alive & All alive & All alive & All alive & All alive \\
\hline 5 & 0.5 & All alive & All alive & All alive & All alive & All alive & All alive & $\begin{array}{c}\text { All alive } \\
\text { with reduced activity }\end{array}$ \\
\hline 5 & 0.1 & All alive & All alive & All alive & All alive & All alive & $\begin{array}{c}\text { All alive } \\
\text { with reduced activity }\end{array}$ & $\begin{array}{c}\text { All alive } \\
\text { with reduced activity }\end{array}$ \\
\hline
\end{tabular}

Table 2: Probit analysis of the mortality data of Channa punctatus exposed to different concentrations of carbaryl

\begin{tabular}{|c|c|c|c|c|c|c|}
\hline $\begin{array}{c}\text { Serial } \\
\text { No. }\end{array}$ & $\begin{array}{c}\text { Concentration in } \\
\text { mg/ Litre }\end{array}$ & $\begin{array}{c}\text { Log of } \\
\text { concentration }\end{array}$ & $\begin{array}{c}\text { No. of Channa } \\
\text { punctatus exposed }\end{array}$ & $\begin{array}{c}\text { No. of Channa punctatus died } \\
\text { during 30 min exposure period }\end{array}$ & $\begin{array}{c}\text { \% } \\
\text { Mortality }\end{array}$ & $\begin{array}{c}\text { Probit } \\
\text { value }\end{array}$ \\
\hline 1. & 0.00 & Control & 10 & 00 & 00 & - \\
\hline 2. & 0.10 & 1.00000000000 & 10 & 00 & 00 & 3.04 \\
\hline 3. & 0.50 & 0.30102999566 & 10 & 00 & 00 & 3.04 \\
\hline 4. & 1.00 & 0.00000000000 & 10 & 00 & 00 & 3.04 \\
\hline 5. & 1.11 & 0.04532297878 & 10 & 06 & 40 & 4.75 \\
\hline 6. & 1.15 & 0.06069784035 & 10 & 10 & 60 & 5.25 \\
\hline 7. & 1.17 & 0.06818586174 & 10 & 10 & 100 & 97.5 \\
\hline 8. & 1.22 & 0.08635983067 & 10 & & 100 & 97.5 \\
\hline
\end{tabular}




\begin{tabular}{|l|l|l|l|l|l|l|}
\hline 9. & 1.25 & 0.09691001300 & 10 & 10 & 100 & 97.5 \\
\hline 10 & 1.31 & 0.11727129565 & 10 & 10 & 100 & 97.5 \\
\hline
\end{tabular}

\section{Discussion}

Fish are ideal sentinels for behavioural assays of various toxic chemical exposures due to their constant and direct contact with the aquatic environment where chemical exposure occurs over the entire body surface. Behaviour provides a unique perspective linking the physiology and ecology of an organism and its environment (Little and Brewer, 2001) ${ }^{[12]}$. Behaviour allows an organism to adjust to external and internal stimuli to the best meet the challenge of surviving in a changing environment. Conversely, behaviour is also the result of adaptations to environmental variables. Thus, behaviour is a selective response that is constantly adapting through direct interaction with physical, chemical, social, and physiological aspects of the environment.

In the present studies exposure to carbaryl caused alterations in the behaviour of Channa punctatus. At the concentrations $1.17 \mathrm{ppm}$ or above fish became restless, showed abnormal movements, and died. Below this concentration fishes remained alive, but they faced problem to maintain the normal working of their body. The colour of the skin was changed due to exposure to this compound. It was faded and after 20 days of exposure their skin colour became noticeably light the pigmentation in the skin was decreased with increase in exposure period. Sometimes they stretched their body and tried to jump out of aquarium. At higher concentrations of carbamates and synthetic pyrethroids the fishes became lethargic, their swimming became abnormal, their body was tilted, and they lost their balance.

Since behaviour is not a random process, but rather a highly structured and predictable sequence of activities designed to ensure maximal fitness and survival of the individual, behavioural endpoints serve as valuable tools to discern and evaluate effects of exposure to environmental stressors. Fish can uptake and retain different xenobiotics dissolved in water via active or passive processes. They can be used to detect, and document pollutants released into their environment. Sublethal concentrations of pesticides in aquatic environments cause structural and functional changes in aquatic organisms and this is more common than mortality (Sancho et al., 2003) [18]. Behavioural modification is one of the most sensitive indicators of environmental stress and may affect survival (Olla et al., 1983 and Byrne and O'Halloran, 2001) ${ }^{[14,2] .}$ Alterations in fish behaviour, particularly in non-migratory species, can also provide important indices for ecosystem assessment. Any change in the behaviour of fish indicates the deterioration of water quality, as fish are the biological indicator and hence index of environmental suitability and the cost of survival. Most physiological and environmental changes can induce variations in fish behaviour (IsraeliWeinstein and Kimmel, 1998; Almazán-Rueda et al., 2004) ${ }^{[9,}$ 1]. Carbaryl has been reported to cause genotoxic effect in Channa punctatus (Chaudhari and Saxena, 2020) ${ }^{[3]}$. The observations in the present study also showed the changes in the behaviour of Channa punctatus due to presence of carbaryl in surrounding medium

\section{Conclusion}

The results presented in this study clearly show that exposure to carbaryl even at extremely low concentrations cause changes in the behaviour and structure of Channa punctatus. The changes may affect over all fish health and in turn may also affect other animals including human beings which are consuming this fish as food.

\section{References}

1. Almazán-Rueda P, Schrama JW, Verreth, JAJ. Behavioural responses under different feeding methods and light regimes of the African catfish Clarias gariepinus juveniles. Aquaculture 2004;231(1-4):347359.

2. Byrne PA, O'Halloran J. The role of bivalve molluscs as tools in estuarine sediment toxicity testing: A review. Hydrobiologia 2001;465:209-217.

3. Chaudhari R, Saxena KK. Genotoxic effect of carbaryl on gill cells of Channa punctatus. Paripex-Indian Journal of Research 2020;9:54-55.

4. David A, Ray P. Studies on the pollution of river Daha (N. Bhir) by sugar and distillery wastes. Environmental Health 1966;8:6-35.

5. Draper WM, Street JC. Drift from a commercial aerial application of methyl and ethyl parathion: an estimation of potential human exposure. Bulletin of Environmental. Contamination and Toxicology. 1981;26:530-536.

6. Ecobichon DJ. Occupational hazards of pesticide exposure sampling, monitoring, measuring. Philadelphia Taylor Francis Ecology 1998;17:48-53.

7. Hingoroni HG, Diwan AD, Chandrasekhran N. Oxygen Consumption in fish Labeo rohita under exposition to different concentrations of blood cells in young Baltic Salmon salmosaler L. Acta Physiologica Scandavanica 1979;102:290-300.

8. Huff DL, Batsell RR. Delimiting the arial extent of market area. Journal of Marketing 1977;14:581-585.

9. Israeli-Weinstein D, Kimmel E. Behavioural response of carp, Cyprinus carpio to ammonia stress. Aquaculture, 1998;165(1):81-93.

10. Kim Oanh NT. A comparative study of effluent toxicity for three chlorine-bleached pulp and paper mills in Southeast Asia. Resources Conservation and Recycling. 1996;18:87-105.

11. Kumari AN, Ram Kumari S. Effect of polluted water on histochemical localization of carbohydrates in a freshwater teleost $C$. punctatus form Hussain Sugar Lake Hyderabad Andhra Pradesh. Pollution Research 1997;16:197-200.

12. Little EE, Brewer SK. Neurobehavioral toxicity in fish. In: D. Schlenk and W.H. Benson (Ed.), Target Organ Toxicity in Marine and Freshwater Teleosts. New Perspectives: Toxicology and the Environment, Taylor and Francis, London and New York 2001;2:139-174.

13. Metcalfe RL. Insect control technology. In: Kirk-Othmer Encyclopedia of Chemical Technology. John Wiley and Sons, New York 1995, 533-602.

14. Olla BL, Bejda AJ, Pearson WH. Effects of oiled sediment on the burrowing behavior of the hard clam, Mercenaria mercenaria. Marine Environmental Research 1983;9:183-193.

15. Quasim SZ, Siddique RH. Preliminary observation on the river kali caused by the effluent of industrial waste. Current Science 1960;29:310-311.

16. Ramona A, Biswas AK, Kundu S, Saha JK, Yadav RBR. Efficacy of distillery effluent on seed germination and seedling growth in mustard, cauliflower and radish. Proceedings of National Academy of Sciences, India. 
2001;71(bII):129-135.

17. Rishi KK, Grewal S. Chromosomal aberration test for the insecticide. Dichlorvos on fish chromosomes. Mutation Research Genetic Toxicology 1995;344(1-2):1-4.

18. Sancho E, Fernandez-Vega C, Ferrando MD, AndreuMoliner E. Eel ATPase activity as biomarker of thiobencarb exposure. Ecotoxicology and Environmental Safety 2003;56:434-441.

19. Saxena KK, Seth N. Toxic effects of cypermethrin on certain hematological aspects of freshwater fish Channa punctatus. Bulletin of Environmental Contamination and Toxicology 2002;69:364-369.

20. Venkataraman G. A note on the occurrence of largescale fish mortality along the Chaliyar near Beypore. Journal of Marine Biological Association, India 1966;8:224.

21. Yen NT, Oanh NTK, Reutergardh LB, Wise DL, Lan NTT. An integrated waste survey and environment effects of COGIDO, a bleached pulp and paper mill in Vietnam on the receiving water body. Resource Conservation and Recycling 1996;18:61-73. 